\title{
BIOGEOGRAPHICAL CHARACTERIZATION OF THE MARANHENSE EASTERN MESOREGION (BRAZIL)
}

\author{
Gustavo Pereira Lima ${ }^{1, *}$; Carlos Alberto Algarves Peixoto Neto1; Yuri Teixeira Amaral1,a and Glécio \\ Machado Siqueira²
}

\begin{abstract}
${ }^{1}$ Mestrando no Programa de Pós-Graduação em Biodiversidade e Conservação, Universidade Federal do Maranhão, São Luís, Brazil. ${ }^{2}$ Professor, Departamento de Geociências, Universidade Federal do Maranhão, São Luís, Brazil. a)Instituto Chico Mendes de Conservação da Biodiversidade.

*Corresponding author: gustavo-plima@hotmail.com
\end{abstract}

\begin{abstract}
This review aims to study the main aspects of Maranhense East Mesoregion Biogeography of the state portion has suffered socio-economic and cultural changes, besides environmental conflicts due to the advance of capitalist agriculture as soy and eucalyptus agribusiness. The Maranhense East Mesoregion is formed by the union of 44 cities grouped into six microregions: Chapadinha, Coelho Neto, Baixo Parnaíba Maranhense, Chapada do Alto Itapecuru, Codó, and Caxias. Historically, this mesoregion had its occupation linked to peripheral areas to the large cotton plantations of the Itapecuru and cattle creation in Pastos Bons, in the XVII and XVIII century. The economy of this mesoregion is mainly based on Eucalyptus for pulp and paper, soybean, maize, and sugarcane. It must be emphasized that the introduction of the soybean, sugarcane, the expansion of eucalyptus and the charcoal production increased the pollution of the rivers and the destruction of native resources. The lack of inspection as to legal reserve areas in rural properties and the lack of conservation units in this region may be considered as aggravating in relation to the intense expansion of agricultural activities. The vegetation of the Maranhense East Mesoregion encompasses several formations, being basically characterized by the forests of babassu and the areas of cerrado latu senso, besides the small patches of Caatinga near the border with the state of Piaui and transitional formations. The climate is typical of tropical zones, predominantly As in the Parnaíba Delta region and the Aw throughout the rest of the mesoregion, with annual average temperatures between $24^{\circ} \mathrm{C}$ to $28^{\circ} \mathrm{C}$ and precipitation index with values between $1800 \mathrm{~mm}$ to $1000 \mathrm{~mm}$. The studied mesoregion has only five Conservation Unit: Mirador State Park, Morros Garapenses State Environmental Protection Area, Parnaíba Delta Environmental Protection Area, Parnaíba Delta Marine Extractive Reserve, Chapada Limpa Extractive Reserve.
\end{abstract}

Key words: Maranhão geography, environmental conservation, socioeconomic aspects.

\section{CARACTERIZAÇÃO BIOGEOGRÁFICA DA MESORREGIÃO LESTE MARANHENSE (BRASIL)}

RESUMO: Esta revisão tem como objetivo estudar os principais aspectos da Biogeografia da Mesorregião Leste Maranhense, porção do estado que tem sofrido mudanças socioeconômicas e culturais, além de conflitos ambientais devido ao avanço da agricultura capitalista como o agronegócio da soja e eucalipto. A Mesorregião Leste Maranhense é formada pela união de 44 municípios agrupados em seis microrregiões: Chapadinha, Coelho Neto, Baixo Parnaíba Maranhense, Chapadas do Alto Itapecuru, Codó e Caxias. Historicamente, esta mesorregião teve sua ocupação ligada às áreas periféricas às grandes plantações de algodão do Itapecuru e criação de gados em Pastos Bons, no século XVII e XVIII. A economia desta mesorregião baseia-se principalmente no Eucalipto para a produção de celulose e papel, soja, milho e cana-de-açúcar. Deve-se ressaltar que a introdução da soja, da cana-de-açúcar, a expansão do eucalipto e a produção de carvão vegetal aumentaram a poluição dos rios e a destruição de recursos nativos. A falta de fiscalização quanto às áreas de reserva legal nas propriedades rurais e a falta de unidades de conservação nesta região, podem ser consideradas como agravantes em relação à expansão intensa das atividades agropecuárias. A cobertura vegetal da mesorregião Leste maranhense engloba várias formações, sendo basicamente caracterizada pelas florestas de babaçu e pelas áreas de cerrado lato senso, além das pequenas manchas de caatinga próximas à fronteira com o estado do Piauí e formações transicionais. O clima da região é característico das zonas tropicais, predominantemente As na região do Delta do Parnaíba e o Aw em todo o restante da mesorregião, com temperaturas médias anuais entre $24^{\circ} \mathrm{C}$ até $28^{\circ} \mathrm{C}$ e índices de precipitação pluviométrica com valores entre $1800 \mathrm{~mm}$ a $1000 \mathrm{~mm}$. A mesorregião estudada apresenta apenas cinco Unidades de Conservação: Parque Estadual do Mirador, Área de Proteção Ambiental Estadual dos Morros Garapenses, Área de Proteção Ambiental do Delta do Parnaíba, Reserva Extrativista Marinha do Delta do Parnaíba, Reserva Extrativista de Chapada Limpa.

Palavras-chave: Geografia do Maranhão, conservação ambiental, aspectos socioeconômicos. 


\section{INTRODUCTION}

This mesoregion currently is formed by the union of 44 municipalities grouped into six microregions, which are: Baixo Parnaíba Maranhense, Caxias, Chapada do Alto Itapecuru, Chapadinha, Codó and Coelho Neto (Table 1; Figure 1). Concatenating a total area of $70,606.230 \mathrm{~km}^{2}$ and a total population estimated at 1,352,919 inhabitants (Botelho et al., 2012).
Many cities belonging to this mesoregion present great importance such historically as current in the state scenario, as Timon, Caxias, and Codó, being these are also among the ten most populous cities of Maranhão, according to the last census conducted by the Brazilian Institute of Geography and Statistics (IBGE, 2016).
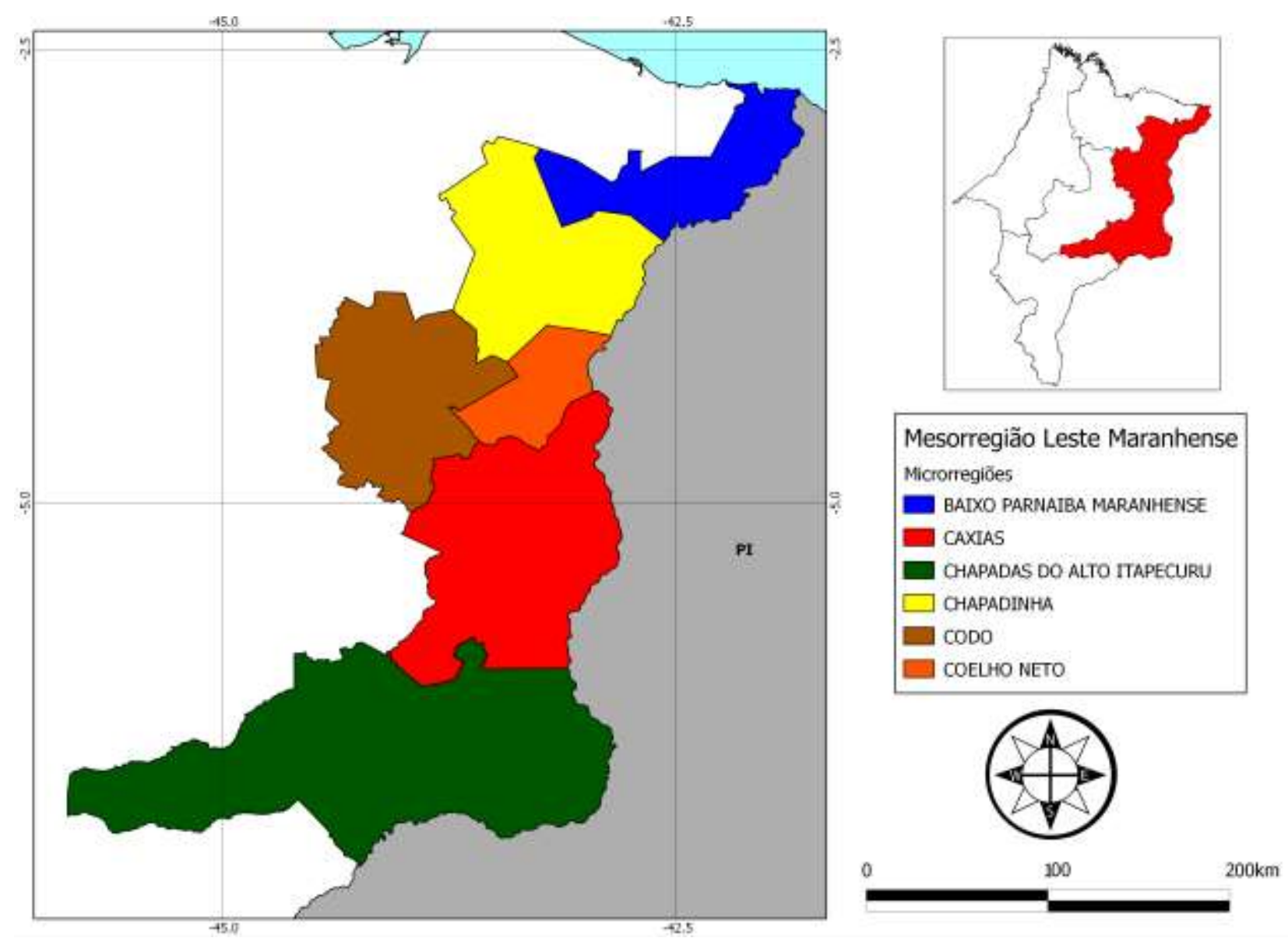

Figure 1. Location map of the Maranhense East Mesoregion and its microregions (Maranhão State, Brazil).

Historically, this mesoregion had its occupation linked to the peripheral areas of large cotton plantations of the Itapecuru and the creation of cattle in Pastos Bons, in the XVII and XVIII centuries (Rios, 2005; Cunha,
2015). In the land of XIX century, began to receive loads of workers from Bahia, Piauí, and Ceará, mainly, due to the dry season problems in these states (Gaspar and Andrade, 2014; Cunha, 2015). 
From the 1980s, have been settled in the microregions of Baixo Parnaíba and Chapadinha, national and foreign companies focused on the production of charcoal and eucalyptus plantation (Botelho et al., 2012). The production of charcoal derived from the burning of some species of native woods was intended, among other activities, to food pig iron in Maranhão Gusa S/A steel mill. Already the eucalyptus plantations aimed the pulp production, having the Industrial Group João Santos in Pernambuco (Brazil) and Suzano Celulose in São Paulo (Brazil) as major companies (Rios, 2005; Gaspar and Andrade, 2014).

Table 1. Data of the Eastern microregions of Maranhão (Brazil).

\begin{tabular}{|c|c|}
\hline MICRORREGIONS & CITIES \\
\hline Baixo Parnaíba Maranhense & $\begin{array}{l}\text { Água Doce do Maranhão; Araioses; Magalhães de Almeida; Santa Quitéria do Maranhão; } \\
\text { Santana do Maranhão; São Bernardo. }\end{array}$ \\
\hline Caxias & Buriti Bravo; Caxias; Matões; Parnarama; São João do Soter; Timon. \\
\hline Chapada do Alto Itapecuru & $\begin{array}{l}\text { Barão de Grajaú; Colinas; Jatobá; Lagoa do Mato; Mirador; Nova lorque; Paraibano; } \\
\text { Passagem Franca; Pastos Bons; São Francisco do Maranhão; São João dos Patos; } \\
\text { Sucupira do Norte; Sucupira do Riachão. }\end{array}$ \\
\hline Chapadinha & $\begin{array}{l}\text { Anapurus; Belágua; Brejo; Buriti; Chapadinha; Mata Roma; Milagres do Maranhão; São } \\
\text { Benedito do Rio Preto; Urbano Santos. }\end{array}$ \\
\hline Codó & Alto Alegre do Maranhão; Capinzal do Norte; Codó; Coroatá; Peritoró; Timbiras. \\
\hline Coelho Neto & Afonso Cunha; Aldeias Altas; Coelho Neto; Duque Bacelar. \\
\hline
\end{tabular}

After more than twenty years these processes has been further increased, with the introduction of the Industrial based agriculture, such as soybeans. The expansion of soy in the Eastern of Maranhão, mainly in the Chapada do Alto Itapecuru and in the Baixo Parnaíba, demonstrate that this region is in the sights of the same producers, which have expanded considerably in the South mesoregion of Maranhão, popularly known as the "gauchos" (Rios, 2005; Gaspar and Andrade, 2014). Another modernized agricultural activity that has been outstanding is the production of sugarcane, which employs the modern technology of cultivation and full utilization of the raw material. Its production center is concentrated in two cities, considered as sugar-alcohol poles in the state, being they: Coelho Neto e Aldeias Altas (Rios, 2005).

Finally, it should be emphasized that the introduction of soybeans, of extensive livestock, of sugarcane, the expansion of eucalyptus and the charcoal production, had increased the pollution of rivers and the devastation of native resources, for example, in Upper Itapecuru and the region of Baixo Parnaíba (Rios, 2005). The lack of inspection as the legal reserve areas in the properties, the practices conducted by the producers and the lack of conservation units can be considered as aggravating factors in relation to the intense expansion of agricultural activities in this region. 


\section{CLIMATE}

In general, the average annual temperature in this part of the state is not so distinct from other regions, presenting averages between $24{ }^{\circ} \mathrm{C}$ until $28^{\circ} \mathrm{C}$ (NUGEO, 2016; CNPM, 2016). However, the rainfall question is observed marked differences in the levels, since the precipitation values in the west and northern of the state are higher than in the eastern and southern region of Maranhão (Rios, 2005; Sousa et al, 2013). The rainfall precipitation index in this region remain with values between $1800 \mathrm{~mm}$ and $1100 \mathrm{~mm}$ (Figure 2), and even lower values can occur (Sousa et al., 2013).

Another important data to be emphasized, is the hydric deficit of the region, being this the result of a greater rainfall seasonality, which consequently is related to a larger amount of dry months (Figure 3). This phenomenon mentioned anteriorly is had with a reflection of greater proximity with the Caatinga region (Nimer, 1989; Rios, 2005).

In relation to Koppen classification, which takes into account the climatic features mentioned above, is observed from the available macroscale maps on the recent revision of this classification in the country by Alvares et al. (2014), Maranhão eastern zone has two feature climatic types of tropical areas: As the Delta region of Parnaíba and the Aw throughout the rest of this mesoregion.
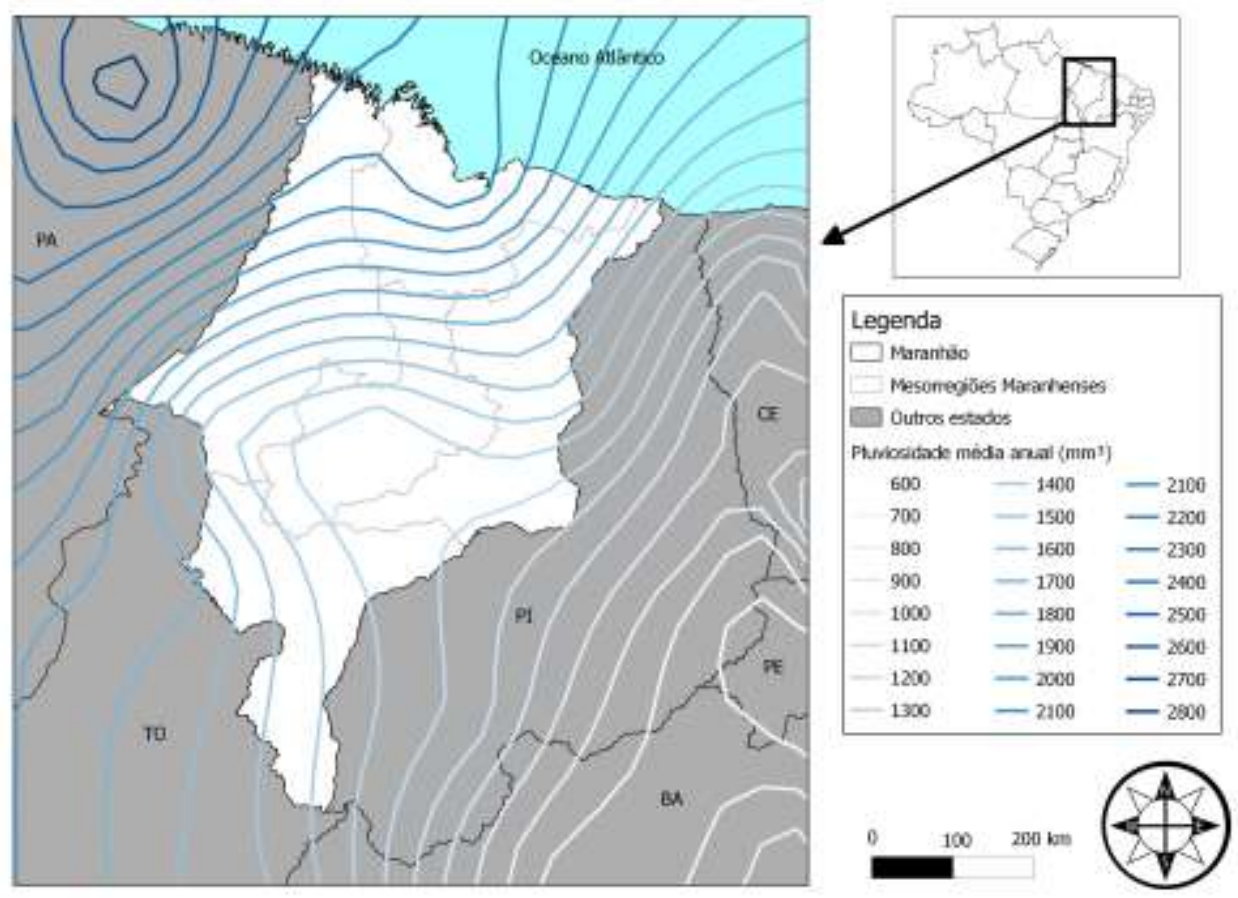

Figure 2. Isohyets of rainfall precipitation in the state of Maranhão. Highlighted, the delimitation of the Eastern Mesoregion in the state of Maranhão. Source: MMA (2016). 


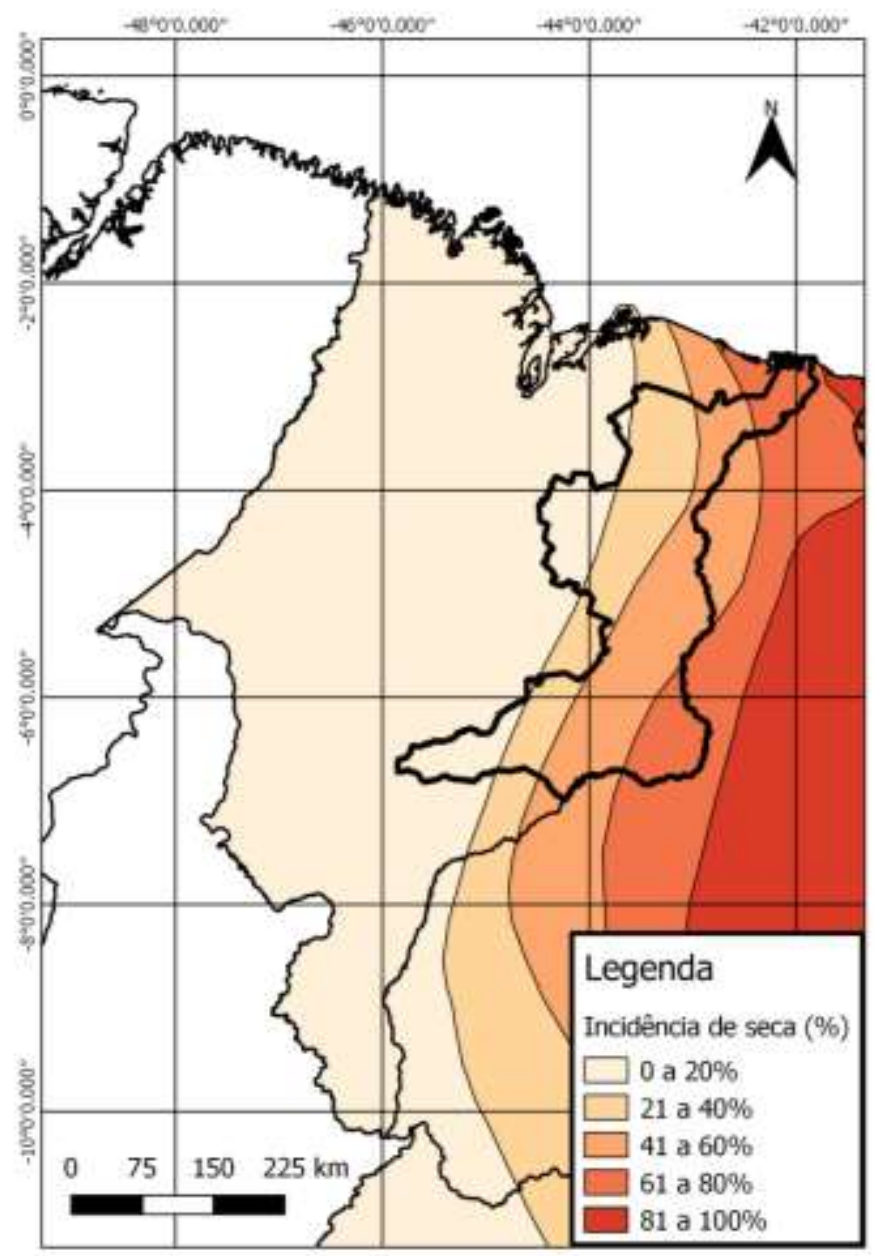

Figure 3. Dry incidence in the state of Maranhao. Highlighted, the delimitation of the Eastern Mesoregion in the state of Maranhão. Source: MMA (2016).

\section{BASINS HYDROGRAPHICS}

According to MMA (2016), the eastern region of Maranhão is comprised by Hydrographic Regions of the Eastern Northeast Atlantic and of Parnaíba (Figure 4), being these constituted, by the basins of Parnaíba, Munim, Itapecuru and Preguiças rivers (Sousa et al., 2013).

The Parnaíba River is the main river of the Middle North and is considered as a vital source for big part of the population of Maranhão and Piauí State (Brazil). From an economic point of view, this river is linked to numerous activities developed by the populations of the surroundings, such as fish farming and agriculture, in addition to having as particularity the supply of electricity through the Boa Esperança hydroelectric, also known as Presidente Castelo Branco (Rios, 2005). Another point to be noted for this basin is the Parnaiba Delta, considered one of most extensive in the world, with numerous insular formations at its mouth (El-Robrini et al., 2006).

The Itapecuru River is inserted almost entirely in this mesoregion of the state, being born in the system formed by the Croeira, 
Itapecuru and Espadrilles Hills, and crossing almost $1,050 \mathrm{~km}$ before flowing into the Arraial Bay (Rios, 2005; NUGEO, 2016). The Itapecuru river is most extensive and most navigable Maranhense river, which bathes numerous important cities, such as Mirador Colinas, Codó, Timbiras, and Coroatá, besides being pegged to the foundation of most of the eastern Maranhense cities.
Finally, there is the Munim River, which is present in a small portion of the eastern mesoregion of the State, precisely the region that comprises the main zones of drainages and springs of this river, which are located on the boards of the Barrier Formation, northeast of the city of Caxias (Rios, 2005; NUGEO, 2016).

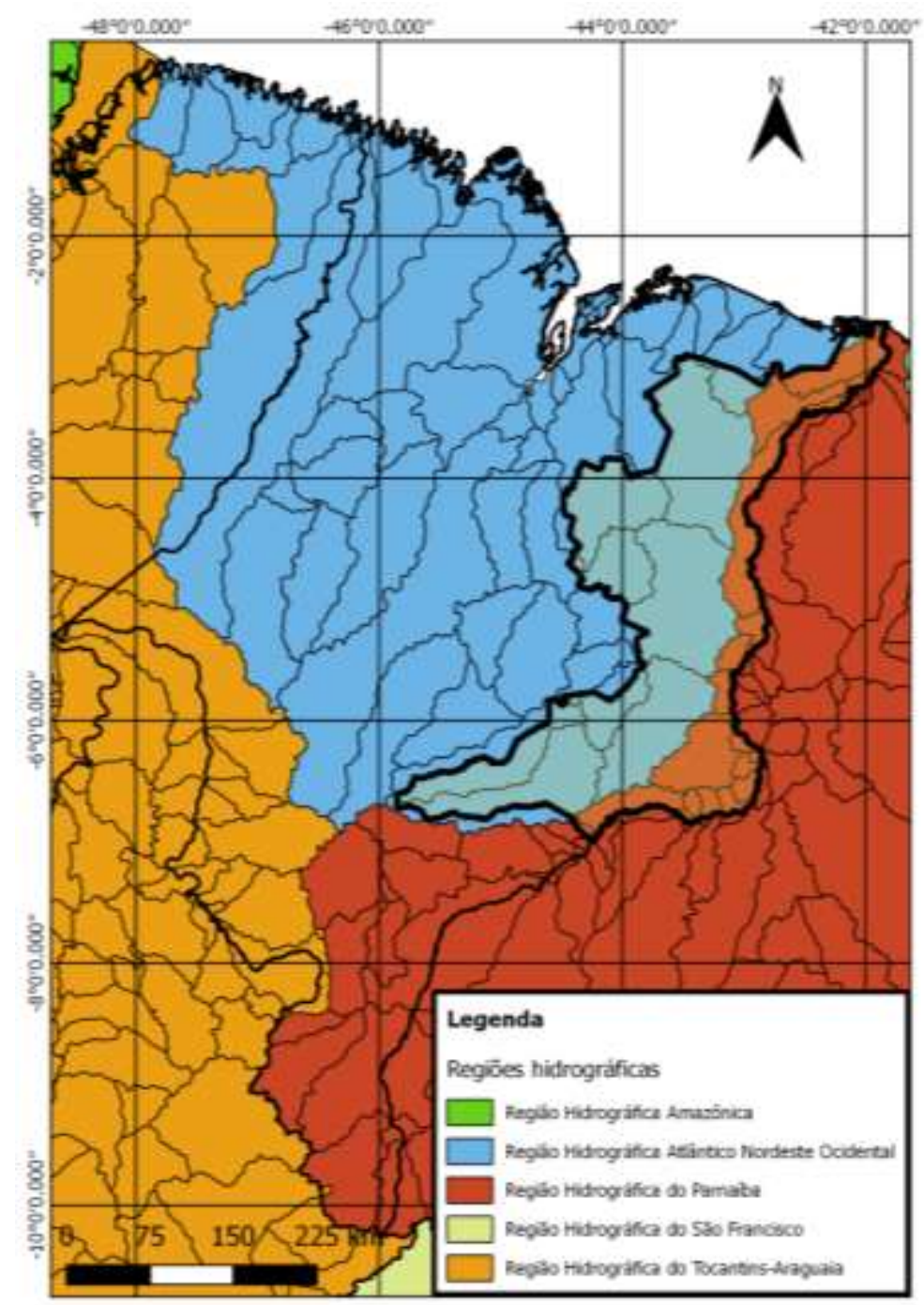

Figure 4. Hydrographic Regions in Maranhão Map. Highlighted (hatched part), the units present in Mesoregion Eastern State. Souce: MMA (2016).

\section{GEOMORPHOLOGICAL DOMAINS}

Based on the maps available by Dantas et al. (2013), the eastern maranhense can be distinguished by presenting the following geomorphological domains: Parnaíba Delta, 
Lençóis Maranhenses, Chapadinha Boards, flattened surfaces of the Parnaíba River Basin, Tabular surfaces of the Basins of Itapecuru and Munim rivers, Tabular Surfaces Basins of Parnaíba River and Upper Itapecuru River Chapada. Some descriptions of these geomorphological domains are reported below, being these a summary of the data available by Dantas et al. (2013):

- $\quad$ Parnaíba Delta - On the eastern end of Maranhense Coastal Plain, develops the Parnaiba Delta, the most well designed deltaic feature in a fluvial fan of the Brazilian coast, located between the states of Piaui and Maranhão. The western portion of the Parnaiba Delta is located in the state of Maranhão and is bounded on the south and west by the Lençóis Maranhenses. This unit, characterized by a deltaic environment of the interface between the fluvial and marine sedimentary systems, presents a diversified set of depositional features of fluvial, fluviomarine, wind and marine origins, with an outstanding domain of the fluviomarine and mangroves plains.

- Lençóis Maranhenses - This domain covers a diversified set of depositional relief patterns of wind origin and represent the most extensive wind sedimentation area in Brazil of quaternary age, presenting great diversity of dunes, such as barchans and parabolic, for example. Predominate soils essentially quartz, very deep, with little adhesion and cohesion between its particles, with low moisture and nutrient retention capacity, corresponding to Quartzarenic Neosols. A part of this domain is found seated in the study mesoregion, comprising, mainly, the vast fields over fixed dunes of Quaternary plains or Coastal Boards, coated with pioneer vegetation or field-cerrado.

- Chapadinha Boards - also called Tablelands Sub-coastal, occupy extensive tabular surface not dissected to the south of the vast fields of fixed dunes of Lençóis Maranhenses. These boards are underpinned by sediments of the Barrier Group and represented by an extensive plateau surface conserved and delimited by short erosional edges, with very soft trim from south to north.

- $\quad$ Flattened surfaces of the Parnaíba River Basin - Occupies narrow and long strip lying west of the Parnaiba River, in its lowermiddle course, being immediately bounded by short cliffs and erosive edges of the Chapadinha Boards and Tabular Surfaces of Itapecuru and Munim River Basins, beyond the Tabular Surfaces of the Parnaíba River, further south.

- Tabular Surfaces of Itapecuru and Munim River Basins - This domain is represented by extensive plateau elevation in modest altitudes and subjected to a differential process of Slotting and denudation, promoting the progressive destruction of the original tabular surface.

- Tabular Surfaces of the Parnaíba River Basin - The Tabular surfaces of the Parnaíba River Basin are represented by a plateau surface intensely dissected, as much by tributaries of the Parnaiba River as by the tributaries of the Balseiro River, a tributary of the Itapecuru River. On these lands develop, 
originally, closed and field-cerrado, interspersed with patches of seasonal deciduous forests.

- Upper Itapecuru River Chapada Represent a relief characterized by a set of plateau surfaces of extensive flat and not dissected tops - chapadões - which stand out, topographically, through rocky cliffs, about 150 to $250 \mathrm{~m}$ above the regional baseline level delimited by the flattened surfaces. Stand out, in this context, the Chapada of Alpercatas, Itapecuru, Crueiras do Agreste and Azeitão. This set of Chapada is individualized by open and depth valleys of rivers Itapecuru, Alpercatas, Neves, Balsas and Balseiro, coated pedimentary deposits and alluvium.

\section{VEGETATION}

The vegetation of Maranhense Eastern mesoregion, as well as throughout the state of Maranhão, comprises an infinity/miscellany of formations (Muniz, 2006).

Predominant, this region is characterized by deciduous seasonal forests, by the areas of lato senso Cerrado, the coastal ecosystems (mangroves and sandbanks), beside the small patches of caatinga near the frontier with the neighboring state of Piaui (Muniz, 2006; IBGE, 2012). Beyond these environments, are notorious the transitional formations, where occur the merge of several typical elements of these diverse environments previously mentioned, which make difficult to characterize the ecosystems in this region of the state (Figure 5).

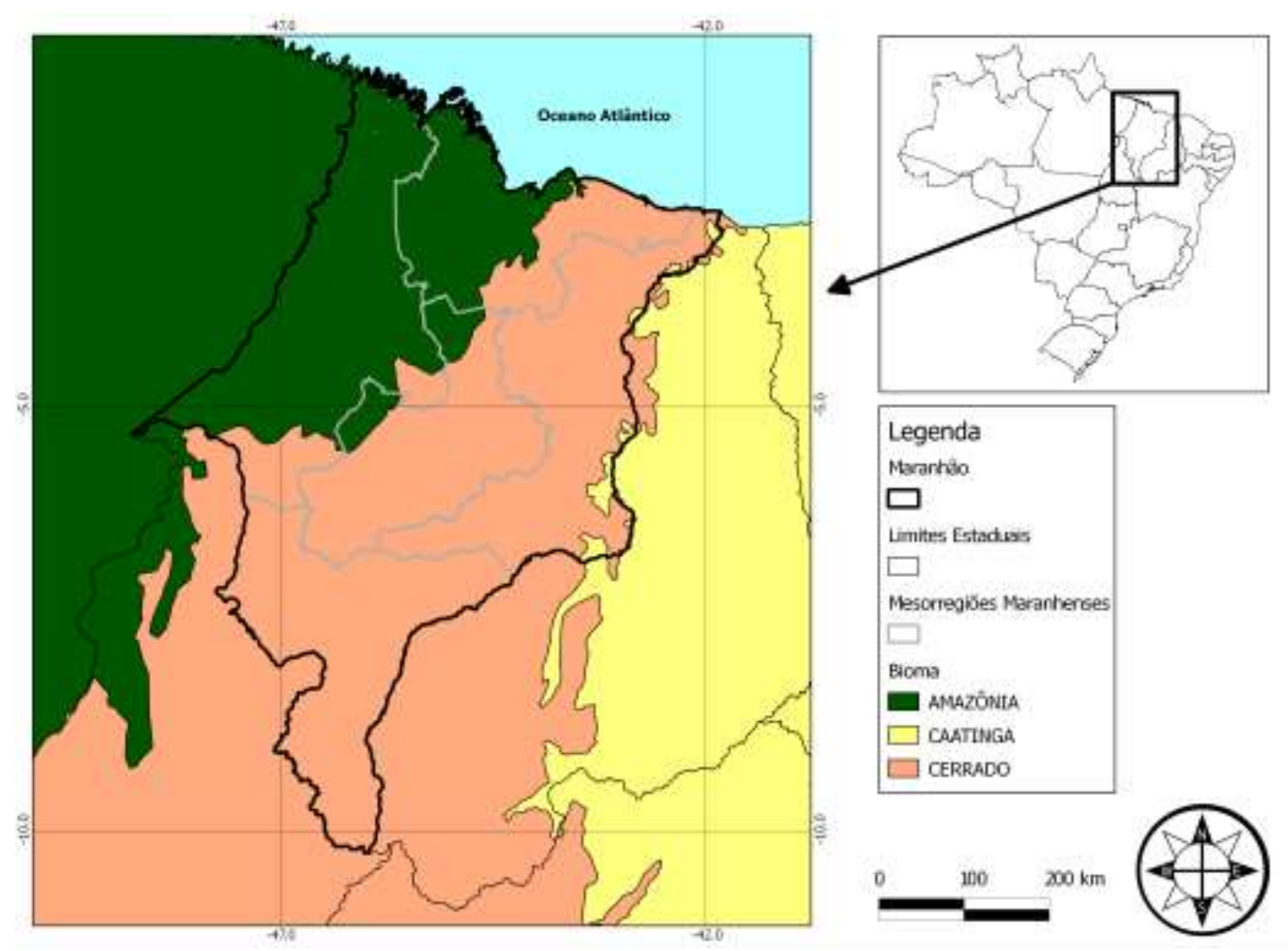

Figure 5. Representation of biomes and ecotones. Highlighted, the biomes located in the Eastern Mesoregion of the State. Source: MMA (2016). 


\section{CONSERVATION UNITS}

According to data available from the Ministry of Environment (MMA, 2016), the studied mesoregion has only seven conservation units so far: the Mirador State Park, Environmental Protection Area of the Morros Garapenses, Environmental Protection Area of the Parnaiba Delta, Marine
Extractive reserve of the Parnaiba Delta, Chapada Limpa Extractive reserve, Environmental Protection Area UpaonAçu/Miritiba/Alto Preguiças and Environmental Protection Area of the mounth of Preguiças River (Figure 6).
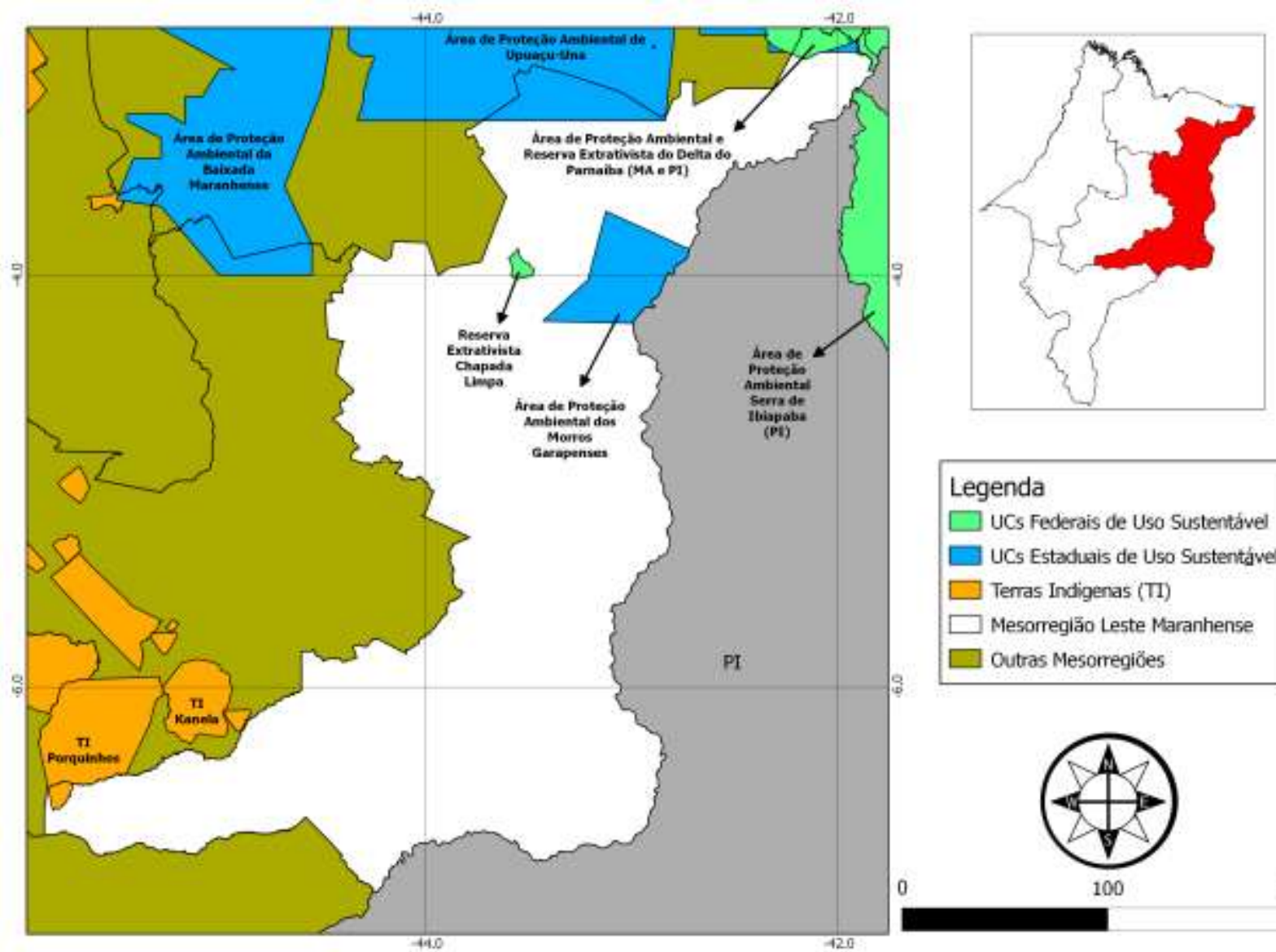

Outras Mesorregiöes
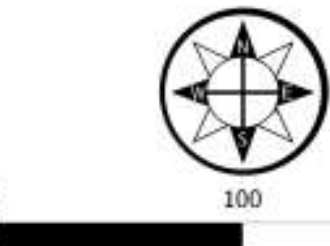

$200 \mathrm{~km}$

Figure 6. Map of the conservation units present in Maranhão. Highlighted the units located in the Eastern Mesoregion of the state.

Some descriptions about these conservation units are related below, being these a summary of the available data on the websites of Brazil's Conservation Units (https://uc.socioambiental.org) and of the Chico Mendes Institute for Biodiversity Conservation database (http://www.icmbio.gov.br),

beyond encompass other developed researches in these regions.

- Morros Garapenses APA- Created by the Government of the State of Maranhão, by the Law No. 25087 of December 31, 2008, this unit covers an area of 234,767 ha, in the cities 
of Buriti, Duque Bacelar, Coelho Neto, and Afonso Cunha. This APA seeks to protect the Cerrado; the protection of transition and contact strips between the Cerrado NorthMaranhenses, the Coconut Palm Forests from the Eastern state and Caatinga, of one large paleobotanical site in Brazil in Brazil, with plant fossils of Permian age (250 million years); the protection of regional ecosystems, which work as habitat of native and migratory species and wildlife refuges from areas already devastated by human activities.

- Mirador State Park - Created by State Decree No. 641 of June 20, 1980, the park comprises an estimated area of 450,838 ha. (Santos \& Conceição, 2010), located between the headwaters of Alpercatas and Itapecuru rivers, a region belonging to the regions of chapadões and plateaus Maranhenses. The area was chosen as a way of protecting the Hydrographic Basin of the Upper Itapecuru, one of the most important of the State, where the headwaters of several formators of the Itapecuru river, responsible for supplying of several Maranhenses cities - including the capital, São Luís. According to Rodrigues and Conceição (2014), the vegetation cover of the unit primarily consists of cerrado, cerradão and gallery forest.

Although, this area is a conservation unit, presents residents, which use the area for pasture and small farms, thus leading the replacement of native cerrado vegetation (Rodrigues and Conceição, 2014).

- Chapada Limpa Extractive Reserve - It was created in 2007, in the city of Chapadinha, State of Maranhão. With an area of approximately 11,971 hectares, the reserve covers mainly cerrado environments, however, also presenting characteristic species of the Amazon and Caatinga. The main activities carried out by the beneficiary traditional communities of the unit are the vegetal extraction (fruit collection of native species) and subsistence agriculture. Currently, about 100 families live inside the unit.

- Extractive Reserve of the Parnaíba Delta - is located in cities of Piaui state (Ilha Grande de Santa Isabel) and Maranhão (Araioses and Água Doce), covering an area of 27,021.69 hectares composed of estuarine and mangroves ecosystems.

- Environmental Protection Area of the Parnaíba Delta - It was created by the Federal Decree of 28 August 1996, with an estimated area of $307,590.51$ ha, covering the cities of Parnaiba, Luis Correia, Ilha Grande and Cajueiro da Praia, in Piauí; Paulino Neves, Tutóia, Araioses and Água Doce do Maranhão in Maranhão; Chaval and Barroquinha, in Ceará. Such as the previous conservation unit, this consists primarily of coastal ecosystems (sandbanks and mangroves) and aim: to protect the deltas of Parnaíba river, Timonha, and Ubatuba, with its fauna, flora and dune complex; protect the remnants of alluvial forest; fostering eco-tourism and environmental education, besides preserving the cultures and local traditions.

\section{FINAL CONSIDERATIONS}

The Maranhense East Mesoregion is mainly characterized by social conflicts and environmental impacts caused by the advance of agriculture in the region, mainly eucalyptus, soybean and sugarcane that are 
mainly responsible for part of the native cerrado loss, among other impacts, on the other hand, this mesoregion had a great social and economic growth, generating employment and income for the state.

\section{REFERENCES}

Alvares, C.A.; Stape, J.L.; Sentelhas, P.C.; Gonçalves, J.L.M.; Sparovek, G. 2014. Koppen's climate classification map for Brazil. Meteorologische Zeitschrift, v. 22, n. 6, p. 711-728.

Botelho, A.C.; Almeida, J.G.; Ferreira, M.G.R. 2012. O avanço dos "Eucaliptais": análise dos impactos socioambientais em territórios camponeses no Leste Maranhense. Revista Percurso - NEMO, v. 4, n. 2, p. 79- 94.

CNPM. 2016. Macrozoneamento EcológicoEconômico do Estado do Maranhão. Disponível em: <https://www.cnpm.embrapa.br/projetos/ma crozee/index.html>. Acessado em: 23 de setembro de 2016.

CPRM. 2016. Companhia de Pesquisa de Recursos Minerais - CPRM. Geobank. Disponível em: <http://www.cprm.gov.br/>. Acessado em: 01 de outubro de 2016.

Cunha, R.C. 2015. Ocupação e o desenvolvimento das duas formações socioespaciais do Maranhão. Cadernos do Núcleo de Análises Urbanas, v.8, n. 1, p. 133152.

Conceição, D.M.; Andrade, L.S.; Cisneros, J.C.; lannuzzi, R.; Pereira, A.A.; Machado, F.C. 2016. New petrified forest in Maranhão, Permian (Cisuralian) of the Parnaíba Basin, Brazil. Journal of South American Earth Sciences, v. 70, p. 308-323.

Dantas, M.E.; Shinzato, E.; Bandeira, I.C.N.; Souza, L.V.; Renk, J.F.C. 2013.
Compartimentação geomorfológica. In: BANDEIRA, I. C. N. (Org.). Geodiversidade do Estado do Maranhão. Teresina : CPRM, 2013. p. 31-62.

El-Robrini, M.; Marques, V.; Silva, M.M.A.; ElRobrini, M.H.S.; Feitosa, A.C.; Tarouco, J.E.F.; Santos, J.H.S.; Viana, J.S. 2006. Erosão e progradação do litoral brasileiro: Maranhão. In: MUEHE, D. (Org.). Erosão e progradação do litoral brasileiro. Brasília: editora São Paulo, 2006. p. 87-130.

Gaspar, R.B.; Andrade, M.P. 2014. Gaúchos no Maranhão: agentes, posições sociais e trajetórias em novas fronteiras do agronegócio. Revista Pós Ciências Sociais, v.11, n.22.

IBGE. Instituto Brasileiro de Geografia e Estatística - IBGE. Cidades. Disponível em: $<$ http://www.cidades.ibge.gov.br/xtras/home. php?lang $=>$. Acessado em: 30 de setembro de 2016.

IBGE. Instituto Brasileiro de Geografia e Estatística - IBGE. Manual Técnico da Vegetação Brasileira. Série Manuais Técnicos em Geociências. 2a ed. Rio de Janeiro: IBGE, 2012.

MMA. Ministério do Meio Ambiente - MMA. Dados Georreferenciados. Disponível em: $<$ http://www.mma.gov.br/areas-

protegidas/cadastro-nacional-de-ucs/dadosgeorreferenciados>. Acessado em: 02 de outubro de 2016.

Muniz, F.H. 2006. A vegetação da região de transição entre a Amazônia e o Nordeste: diversidade e estrutura. In: DE MOURA, E. G. (Org.). Agroambientes de transição: entre o trópico úmido e semi-árido do Brasil. 2a $\mathrm{Ed}$. São Luís: UEMA, 2006. p. 53-70.

Nimer, E. 1989. Climatologia do Brasil. Rio de Janeiro: Instituto Brasileiro de Geografia e Estatística, 1989. 421p. 
NUGEO. Núcleo Geoambiental - NUGEO.

Climatologia. Disponível em:

<http://www.nugeo.uema.br>. Acessado em: 24 de setembro de 2016.

Rios, L. 2005. Geografia do Maranhão. 4. ed. São Luís: Central dos Livros, 2005. 278 p.

Rodrigues, M.S.; Conceição, G.M. 2014. Diversidade florística das diferentes fisionomias de Cerrado do Parque Estadual do Mirador, Maranhão, Brasil. Brazilian Geographical Journal: Geosciences and Humanities research medium, v. 5, n. 1, p. 139-156.

Santos, F.J.L.; Conceição, G.M. 2010. Espécies da brioflora do Parque Estadual do Mirador, Maranhão, Brasil. Cadernos de Geociências, v. 7, n. 2, p. 136-138.

Sousa, C.D.; Melo, D.M.; Nascimento, J.R. 2013. Recursos hídricos superficiais. In: BANDEIRA, I. C. N. (Org.). Geodiversidade do estado do Maranhão. Teresina : CPRM, 2013. p. 77-90. 